\title{
Chemopreventive and Anti-Inflammatory Potential of Select Herbal Teas and Cinnamon in an In-Vitro Cell Model
}

\author{
Shantrell Willis, Rajitha Sunkara, Fredreana Hester, Louis Shackelford, Lloyd T. Walker, \\ Martha Verghese*
}

Department of Food and Animal Sciences, Alabama Agricultural and Mechanical University, Normal, AL, USA

Email: *martha.verghese@aamu.edu

How to cite this paper: Willis, S., Sunkara, R., Hester, F., Shackelford, L., Walker, L.T. and Verghese, M. (2019) Chemopreventive and Anti-Inflammatory Potential of Select Herbal Teas and Cinnamon in an In-Vitro Cell Model. Food and Nutrition Sciences, 10, 1142-1156.

https://doi.org/10.4236/fns.2019.109083

Received: July 3, 2019

Accepted: September 26, 2019

Published: September 29, 2019

Copyright (อ 2019 by author(s) and Scientific Research Publishing Inc. This work is licensed under the Creative Commons Attribution International License (CC BY 4.0).

http://creativecommons.org/licenses/by/4.0/

\section{(c) (i) Open Access}

\begin{abstract}
Colon cancer is the third leading cause of death in the US. Herbal teas and spices may reduce the incidence of chronic diseases, including colon cancer. The objectives of this study were to determine the chemopreventive effects of herbal teas and cinnamon in an in-vitro cell model and to evaluate the inhibitory effects of selected extracts on enzymes associated with inflammatory disease. Effects of raspberry leaf $(0.5-2.0 \mathrm{mg} / \mathrm{mL})$, strawberry leaf $(0.4-1.0$ $\mathrm{mg} / \mathrm{mL})$, hibiscus flower $(4.0-10.0 \mathrm{mg} / \mathrm{mL})$ and cinnamon $(400-1500 \mu \mathrm{g} / \mathrm{mL})$ were evaluated for cytotoxicity, induction of caspase and DNA fragmentation in colon cancer (Caco-2) cells to determine possible chemopreventive effects. Effects of extracts on inhibition of cyclooxygenase-2 (COX-2) were also measured to determine possible anti-inflammatory potential. Caco-2 cells were obtained from American Type Culture Collection (ATCC) and maintained in Dulbecco's Modified Eagle's Medium with 10\% fetal bovine serum. As concentrations of tea increased, LDH release from Caco-2 cells increased, with cytotoxicity ranging from $1 \%-80 \%$ (hibiscus flower $1.0 \mathrm{mg} / \mathrm{mL}$ and strawberry leaf $(1.0 \mathrm{mg} / \mathrm{mL})$ for teas. All extract concentrations of herbal teas and cinnamon were able to enhance caspase- 3 activity with lowest activity $(4.4 \mathrm{mmol} /$ $\mathrm{min} / \mathrm{mL})$ observed in the lowest concentration of cinnamon $(400 \mu \mathrm{g} / \mathrm{mL})$ and highest activity $(6.0 \mathrm{mmol} / \mathrm{min} / \mathrm{mL})$ seen in the highest concentration of raspberry leaf $(2 \mathrm{mg} / \mathrm{mL})$. Tea and spice extracts were able to induce apoptosis in Caco-2 cells exhibited by increased DNA fragmentation (expressed as enrichment factor). Enrichment factor ranged from 1.0 - 1.5 (raspberry leaf 1.0 $\mathrm{mg} / \mathrm{mL}$ and hibiscus $10.0 \mathrm{mg} / \mathrm{mL}$ ). Teas and cinnamon exhibited anti-inflammatory potential by inhibiting COX-2 by $0.6 \%-8.0 \%$ (raspberry leaf 1.0 $\mathrm{mg} / \mathrm{mL}$ and strawberry leaf $0.8 \mathrm{mg} / \mathrm{mL}$ ). The results suggest that herbal teas and cinnamon may have significant benefits in chemoprevention.
\end{abstract}




\section{Keywords}

Colon Cancer, Inflammation, Herbal Tea, Cell Culture

\section{Introduction}

Next to skin cancer, colon cancer is the $3^{\text {rd }}$ most common cancer diagnosed in men and women in the United States. Recent studies estimate for new cases of colon cancer in the US for 2017 are 95,520 [1]. Though detection methods have improved and mortality rates decreased, there is still an urgent need for more preventive methods of cancer. The link between diet and disease is continually researched and it is suggested that diet plays a major role in cancer prevention [2] [3] [4]. It is estimated that approximately $30 \%$ of tumor development may be slowed by improvements in the diet [5] [6]. There is strong evidence of dietary bioactive compounds, such as phytochemicals, and their role in disease prevention. Phytochemicals are secondary plant metabolites that are present within plants to provide protection [7] [8]. Research suggests that phytochemicals in herbal substances may reduce the risk of or prevent cancer [9] [10]. Accounting for these potential benefits is a diverse array of compounds with numerous biological properties.

Chemoprevention describes methods that "reverse or retard tumorigenesis" [11] [12]. Though their chemical and structural nature vary, phytochemicals may act as chemopreventing agents by inducing apoptosis, inhibiting phase I enzyme activity, reducing proliferation and inducing differentiation of cells, and increasing expression of anti-cancer genes [13] [14].

Aside from Camellia sinensis, herbal teas or infusions such as blueberry and bitter melon leaf teas (also known as leafy herbal teas, LHT) are consumed by millions due to their purported health benefits which include reductions in cardiovascular diseases (CVD), diabetes, and cancer [15]. Tea blends are also highly sought after due to their purported health benefits. Some tea blends that are common in the US consist of raspberry leaf, strawberry leaf, and hibiscus flower teas. Tea blends are also often infused with spices for improved taste and increased positive effects on health included the prevention of some chronic diseases such as cancer.

Raspberry leaf tea is derived from the leaves of the raspberry plant, Rubus idaeus and other species of the plant. Also known as the "American Red Raspberry" raspberries are native to Europe and North Asia. Studies conducted have suggested the health benefits of raspberry leaves including, but not limited to anti-inflammatory, antiseptic, antidiarrheic, and gastrointestinal relief [16].

Strawberry leaf tea is derived from the leaves of the plant Fragaria vesca, also known as the wild strawberry and woodland strawberry. There have been numerous health benefits of strawberry fruit, including increased serum antioxidant capacity [17], and anti-thrombotic effects [18]. 
Hibiscus leaf tea is derived from the leaves of the plant Hibiscus sabdariffa. Also known as sorrel, bissap, or sour tea, hibiscus is one of the more common herbal teas incorporated into tea blends in the US [19]. A number of research efforts suggest many health promoting properties of hibiscus including antihypertensive [20], hypocholesterolemic [21], antimicrobial and anticancer [22] effects.

Cinnamon is a well-known spice that had been used widely as both flavoring and medicinal agents for centuries. Though multiple parts of the plant derived from the Cinnamomum genus are used, the bark is most commonly utilized. From the family Lauraceae, the Cinnamomum genus is comprised of approximately 250 species [23], with some common species $C$. burmanni, C. cassia, and C. tamala. Some health benefits of cinnamon include antioxidant and antimicrobial [24], and anti-inflammatory properties [24].

The ability of test compounds, such as herbal teas and spices to induce chemopreventive effects is evaluated using the Caco-2 cell line, which is derived from a human colon adenocarcinoma found in a 72-year old Caucasian male [25] [26].

Cells within the body are tightly regulated; apoptosis occurs when cells are no longer needed and is defined as programmed cell death [27]. Caspases are a family of cysteine dependent proteases that are responsible for regulated apoptosis. Caspases regulate apoptosis by activating DNAse to degrade DNA within the cell nucleus; as a result, the cell dies and undergoes phagocytosis [27]. One of the key hallmarks of cancer is a cancer cell's ability to evade apoptosis. The goal of some chemotherapeutic agents is to induce apoptosis in cancerous cells.

Inflammation is the body's natural response to damage that can result from various sources, including damaged cells [28]. Classified as acute or chronic, inflammation involves activated macrophages and other leukocytes intended to counteract damage within the body [29]. Acute inflammation only lasts for a short period of time, while chronic inflammation has been associated with the development of chronic diseases, such as obesity and cancer [30] [31]. Chronic inflammation leads to an upregulation of pro-inflammatory cytokines, including tumor necrosis factor-alpha (TNF- $\alpha$ ) which aids in the regulation of angiogenesis and tumor development [29].

Cyclooxygenase (COX) is an enzyme responsible for the conversion of arachidonic acid to prostaglandins; prostaglandins are lipid compounds that are essential to inflammation, blood clotting, and factors affecting growth and development [32]. COX has 2 isozymes (COX-1 and COX-2); COX-1 is the constitutive form of the enzyme, while COX-2 is inducible and leads to an increased production of prostaglandins. Factors that affect carcinogenesis, including oncogenes and cytokines, increased COX-2 activity [33]. Therefore, COX-2 inhibition is one potential goal of chemotherapeutic agents. The objectives of this study were to determine the chemopreventive effects of herbal teas and cinnamon in an in-vitro cell model and to evaluate the inhibitory effects of selected extracts on enzymes associated with inflammatory disease. 


\section{Materials and Methods}

All chemicals were obtained from Sigma Chemical Company, St Louis, Mo. and Fisher Scientific Company, Waltham, Mass. Raspberry leaf, strawberry leaf, and hibiscus leaf teas were purchased from Monterey Bay Spice Company (Watsonville, CA). Cinnamon was purchased from a local food market. The cell line (Caco-2) was purchased from the American Type Culture Collection (Manassas, $\mathrm{VA})$.

\subsection{In Vitro Cell Culture Experiment}

\subsubsection{Preparation of Herbal Teas (Strawberry Leaf, Raspberry Leaf, Hibiscus) and Spice (Cinnamon) for Extracts for Cell Culture}

Extracts were prepared following the protocol as described by [34]. Extracts of herbal teas and spices (5 - 10 grams) were prepared by stirring for 2 hr with 100 $\mathrm{ml}$ of $80 \%$ methanol. Mixtures were then centrifuged at $3000 \times \mathrm{g}$ for 20 mins. The supernatant was collected, filtered and evaporated to dryness (Buchi Rotavapor R-200, New Castle, DE). The extraction was reconstituted with $80 \%$ methanol and stored at $-80^{\circ} \mathrm{C}$ until further analysis.

\subsubsection{General Procedures}

Caco-2 human colonic carcinoma cells were obtained from the American Type Culture Collection (ATCC, Manassas, VA). Cells were maintained in Dulbecco's Modified Eagles Medium (DMEM) with 10\% fetal bovine serum. For assay, $5 \times$ $10^{4}$ Caco-2 cells/well were seeded to a 24 -well culture plate and incubated at $37^{\circ} \mathrm{C}$ and $7 \% \mathrm{CO}_{2}$ until development of a monolayer. Cells were incubated (24 $\mathrm{hr}$ ) with serum-free media containing teas and spices at selected concentrations (raspberry leaf $(0.5-2.0 \mathrm{mg} / \mathrm{mL})$, strawberry leaf $(0.4-1.0 \mathrm{mg} / \mathrm{mL})$, hibiscus flower $(4.0$ - $10.0 \mathrm{mg} / \mathrm{mL})$, cinnamon $(400-1500 \mu \mathrm{g} / \mathrm{mL}))$ for lactate dehydrogenase $(\mathrm{LDH})$ release (\% cytotoxicity), histone-related DNA fragmentation, caspase- 3 activity, and for determination of morphological changes. All assays were performed in triplicate.

\subsubsection{Determination of Cytotoxicity}

After $24 \mathrm{hr}$ treatment with serum-free media containing teas and spices, 24-well plates were centrifuged at $1268 \times \mathrm{g}$ for $20 \mathrm{mins}$ at $4^{\circ} \mathrm{C}$. Lactate dehydrogenase $(\mathrm{LDH})$, an enzyme released from mammalian cells during senescence into the culture supernatant, was assayed in cell supernatant, collected after centrifugation. $\mathrm{LDH}$ is detected via the conversion of pyruvate from lactate and formation of formazan. A colorimetric cytotoxicity detection kit (Roche Diagnostics, Indianapolis, IN) was used according to the manufacturer's instructions.

\subsubsection{Determination of Cell Morphology}

There are a number of factors that determine morphology of cells, including intra- and extracellular interactions. Cancer cells such as the Caco-2 line undergo morphological changes that differ from normal cells. Cell morphology was stu- 
died to determine the effect of tea and spice extracts on Caco-2 cells. Treated and untreated Caco-2 cells were fixed, stained (Wright-Giemsa stain), and photographed using an EVOS cell imaging system (Life Technologies, Carlsbad, CA) [35].

\subsubsection{Extraction of Proteins for Enzyme Analysis}

For analysis, $5 \times 10^{6}$ cells/well were placed in 6 well-plates and incubated at $37^{\circ} \mathrm{C}$ until the development of a monolayer. Once monolayer formed, cells were rinsed with PBS and $2 \mathrm{~mL}$ of fresh serum free media containing selected extract concentrations was added to the wells for 24 hours. After aspiration of media, cells were then rinsed with cold PBS and manually collected and centrifuged at $4500 \times \mathrm{g}$ for 20 minutes at $4^{\circ} \mathrm{C}$. Supernatant was then removed and cell lysis buffer was added followed by a freeze-thaw method to cells in order to release active enzymes. Cells lysates (enzymes) were clarified by centrifugation and stored at $-80^{\circ} \mathrm{C}$ until experimentation.

\subsubsection{Caspase-3 Activity}

A caspase determination kit (Promega Corporation, Madison, WI (CaspACE ${ }^{\mathrm{tm}}$ ) was used for measurement of caspase- 3 activity. Based on a yellow color produced by free $p$-nitroaniline (pNA), caspase- 3 was determined in clarified cell lysates.

\subsubsection{Cyclooxygenase (COX-2) Activity}

COX-2 activity kits (Cayman Chemical Company, Ann Arbor, MI) were used to determine inflammatory potential of clarified cell lysates according to the manufacturer's instructions.

\subsubsection{Histone-Related DNA Fragmentation}

Histone related DNA fragmentation in clarified cell lysates was determined using a cell death detection ELISA kit (Roche Diagnostics, Indianapolis IN). The plate reader (490/655 nm) was used for spectrophotometric analysis.

\section{Results and Discussions}

\subsection{LDH}

Lactate Dehydrogenase (LDH) is an essential enzyme this is present is living cells; increased LDH released from cells is a sign of injury or damage to the cell. Caco-2 cells are colon cancer cells and as all cancer cells, these cells evade apoptosis, further avoiding death. Caco-2 cells in the present study were treated with extracts of strawberry leaf (STW), hibiscus flower (HIB), raspberry leaf (RAS) and cinnamon (CIN), after which, LDH release was measured. Increased LDH release from the Caco-2 cells suggest that the herbal tea and spice extracts can cause or induce the death of cancer cells.

Cytotoxic effect of STW, HIB, RAS and CIN on Caco-2 cells was determined by measuring lactate dehydrogenase (LDH) release (Figures 1-4). Increasing concentrations of STW, HIB, and RAS increased LDH release; however, there 
was only a slight increase in percent cytotoxicity of RAS from $0.5 \mathrm{mg}$ to $1 \mathrm{mg}$ concentration of extract. Increasing concentrations of cinnamon increased percent cytotoxicity from extract concentrations of $200 \mu \mathrm{g}$ to $1000 \mu \mathrm{g}$; however, LDH release decreased with $1500-2000 \mu \mathrm{g}$ extract concentrations.

Figure 1 shows percent cytotoxicity in Caco-2 cells treated with strawberry leaf extracts $(0.1 \mathrm{mg} / \mathrm{ml}-1 \mathrm{mg} / \mathrm{ml})$. Cytotoxicity (\%) ranged from a low of 7.81 $(0.1 \mathrm{mg} / \mathrm{ml})$ to a high of $89.06(1 \mathrm{mg} / \mathrm{ml})$. There was an increase in LDH released seen with increased extract concentrations.

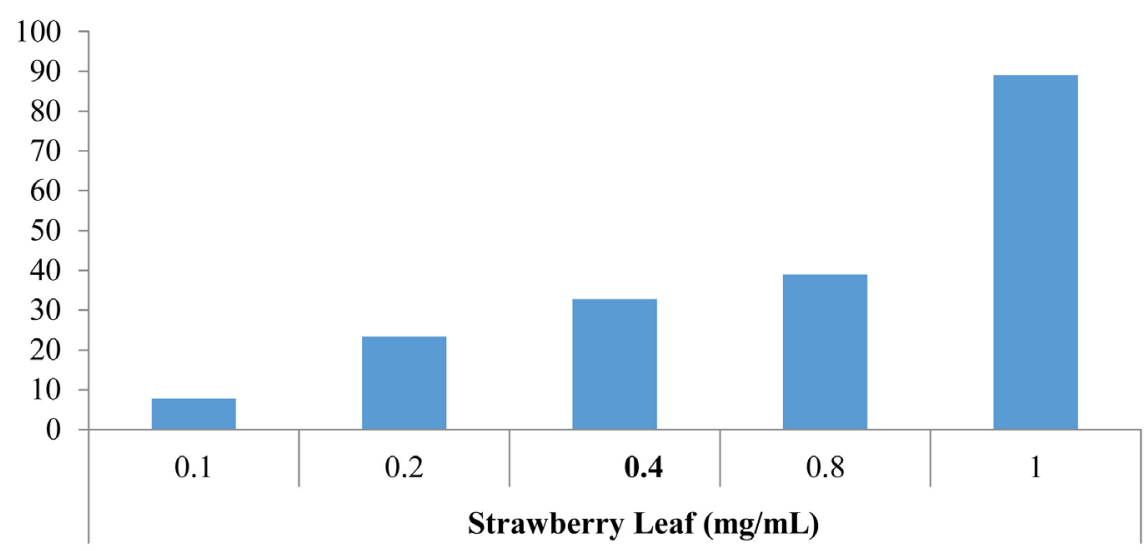

Figure 1. Percent cytotoxicity induced in Caco-2 cells treated (24 hours) with strawberry leaf extract.

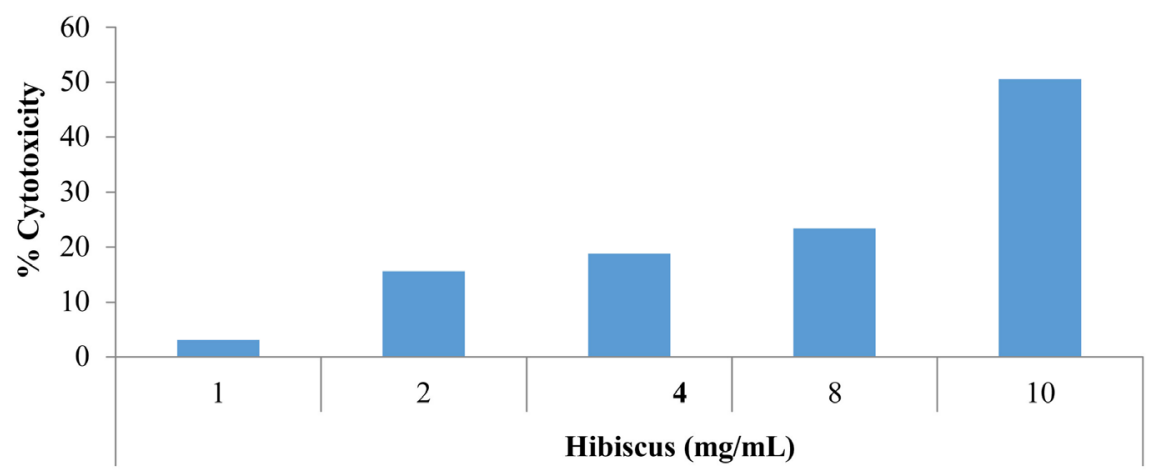

Figure 2. Percent cytotoxicity induced in Caco-2 cells treated (24 hours) with hibiscus flower extracts.

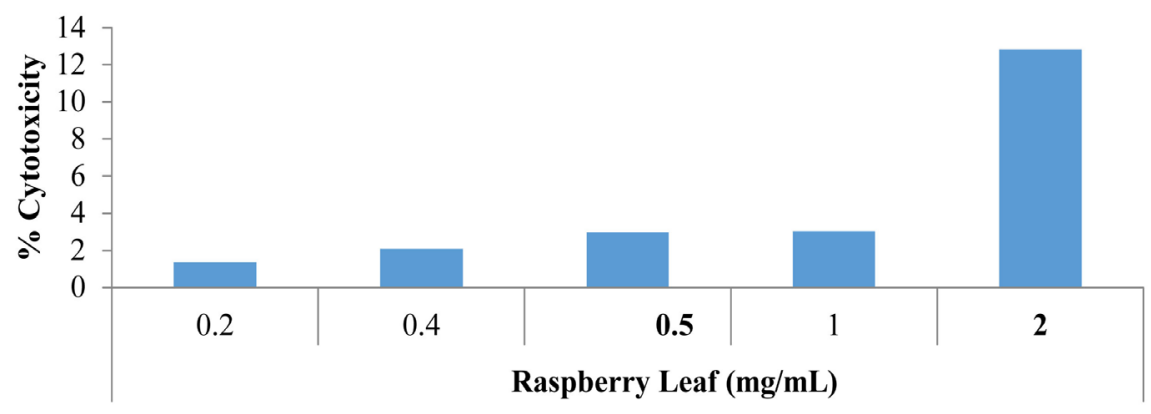

Figure 3. Percent cytotoxicity induced in Caco-2 cells treated (24 hours) with raspberry leaf extract. 


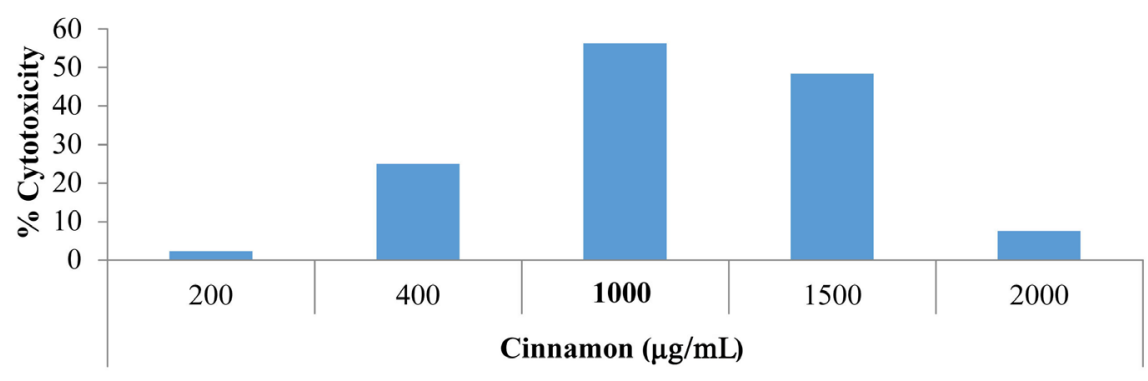

Figure 4. Percent cytotoxicity in Caco-2 cells treated (24 hours) with cinnamon extract.

Figure 2 shows the LDH release (\% cytotoxicity) in Caco-2 cells incubated with hibiscus flower extracts for 24 hours. The highest percent cytotoxicity was seen in cells incubated with the highest concentration $(10 \mathrm{mg} / \mathrm{ml})$ of the extract. With an increase in extract concentration, $(1 \mathrm{mg} / \mathrm{ml}$ to $1 \mathrm{mg} / \mathrm{ml})$, an increase in LDH release was observed, indicating cell damage. The greatest increase in LDH release was seen in cells treated with $10 \mathrm{mg} / \mathrm{ml}$ compared to $8 \mathrm{mg} / \mathrm{ml}$ where LDH more than doubled.

Figure 3 shows the LDH release (cytotoxicity) in Caco- 2 cells incubated with raspberry leaf extracts at concentrations ranging from $0.2 \mathrm{mg} / \mathrm{ml}$ to $2 \mathrm{mg} / \mathrm{ml}$. At lower concentrations, the $\mathrm{LDH}$ release was very low ranging from $1.3 \%$ to $10.7 \%$. However, at the highest concentration $(2 \mathrm{mg} / \mathrm{ml})$, LDH release, indicating cytotoxicity, in the cells was $12 \%$.

Figure 4 shows the cytotoxicity in Caco- 2 cells treated with cinnamon extract for 24 hours. At the lowest and highest concentrations $(200,2000 \mathrm{mg} / \mathrm{ml})$ of cinnamon extracts, the LDH release (\% cytotoxicity) was the lowest, however at $100 \mathrm{mg} / \mathrm{ml}$, LDH release was the highest (55\%).

\subsection{Apoptotic Effect}

One of the hallmarks of cancer is a cancer cell's ability to evade apoptosis. Apoptosis, or programmed cell death occurs when a normal cell is no longer needed, as the cell community is tightly regulated. Caspases are a family of cysteine dependent proteases that are involved in a number of cellular functions, including apoptosis [36] [37] [38]. An increase in caspase-3 activity has been shown to be directly related to a decreased risk of cancer, via the induction of apoptosis [39]. Caspase-3 activity was evaluated after treating Caco-2 cells with raspberry leaf, strawberry leaf, hibiscus and cinnamon extracts. Figures 5-8 show caspase- 3 activity in Caco-2 cells treated with selected concentrations (based on results from LDH cytotoxicity) of herbal teas and cinnamon. Caspase-3 activity results are reported as $\mathrm{mmol} / \mathrm{min} / \mathrm{ml}$.

Figure 8 displays results from cinnamon treated cells. All extract concentrations of herbal teas and cinnamon were able to enhance caspase- 3 activity. Caspase-3 activity of Caco-2 cells treated with raspberry leaf ranged from 4.41 to $6.35 \mathrm{mmol} / \mathrm{min} / \mathrm{ml}$. Strawberry leaf extracts showed a dose effect in regards to caspase- 3 activity in Caco- 2 cells, where the highest activity $(5.53 \mathrm{mmol} / \mathrm{min} / \mathrm{ml})$ 


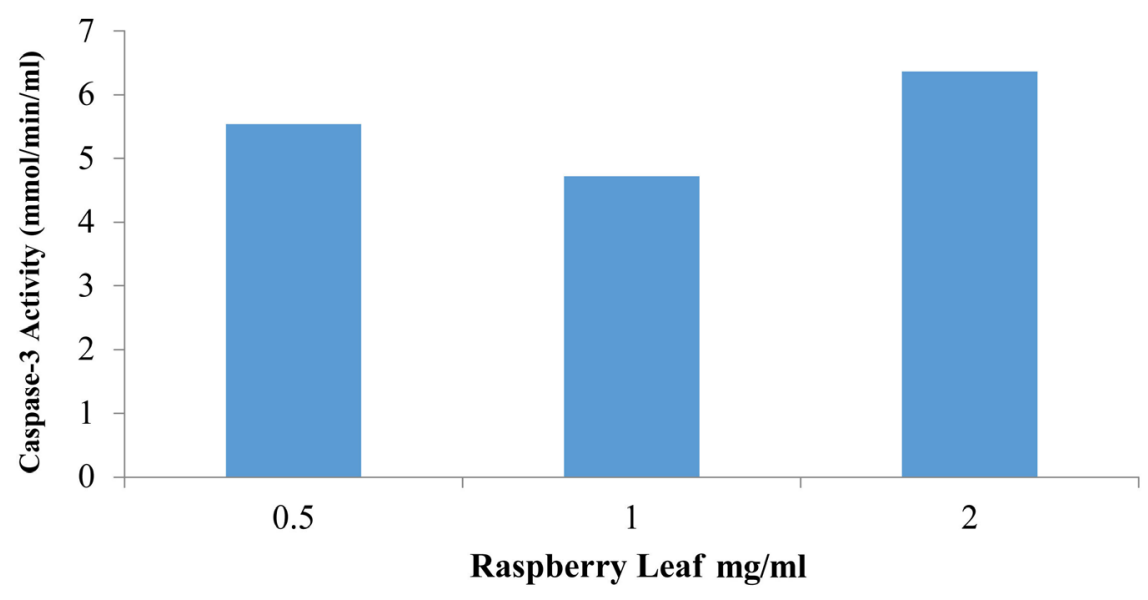

Figure 5. Caspase-3 activity in Caco-2 cells treated (24 hours) with raspberry leaf extract.

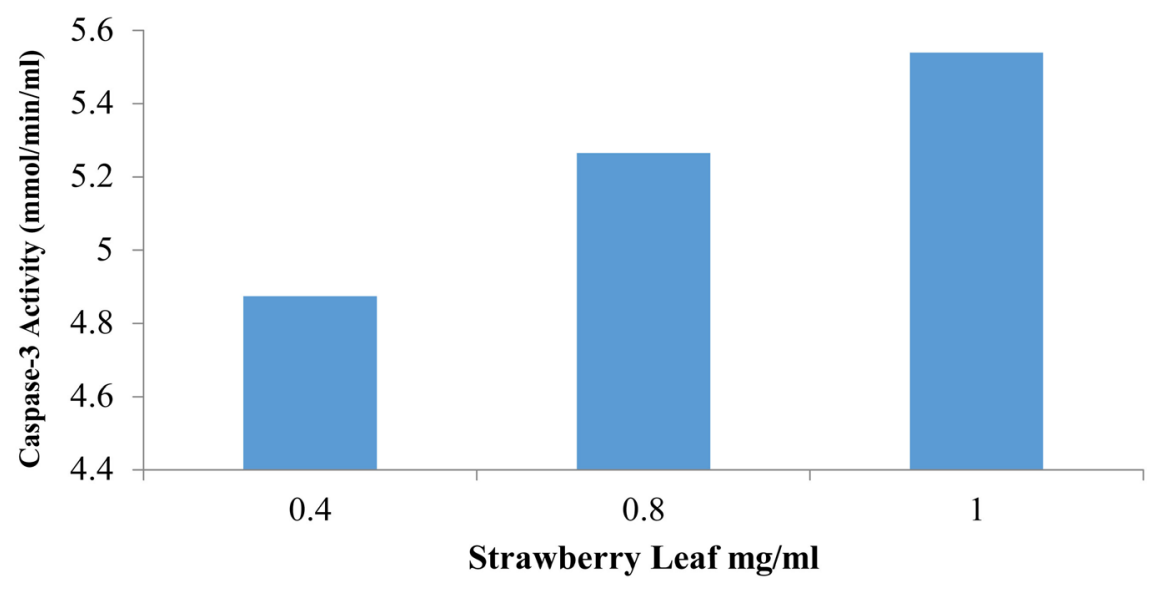

Figure 6. Caspase- 3 activity in Caco- 2 cells treated ( 24 hours) with strawberry leaf extract.

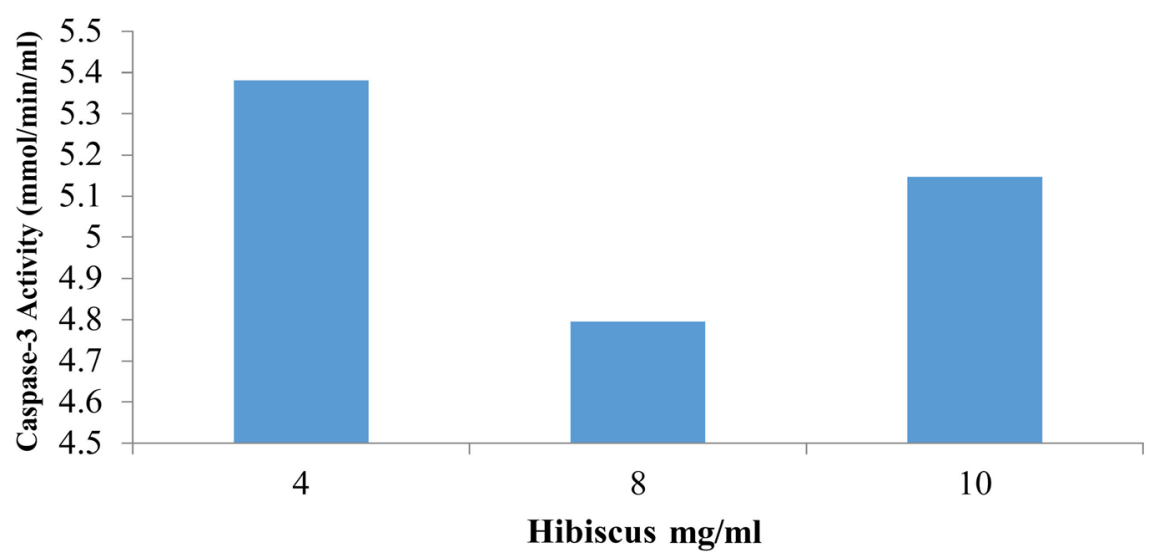

Figure 7. Caspase-3 activity in Caco-2 cells treated ( 24 hours) with raspberry leaf extract.

was seen at an extract concentration of $1 \mathrm{mg} / \mathrm{ml}$. Caco-2 cells treated with hibiscus extracts exhibited caspase-3 activity ranging from 4.79 to $5.38 \mathrm{mmol} / \mathrm{min} / \mathrm{ml}$. Cinnamon extracts increasing from 1000 to $1500 \mu \mathrm{g} / \mathrm{ml}$ exhibited a decrease in caspase-3 activity. A similar trend was seen in cinnamon concentrations (1000 to 


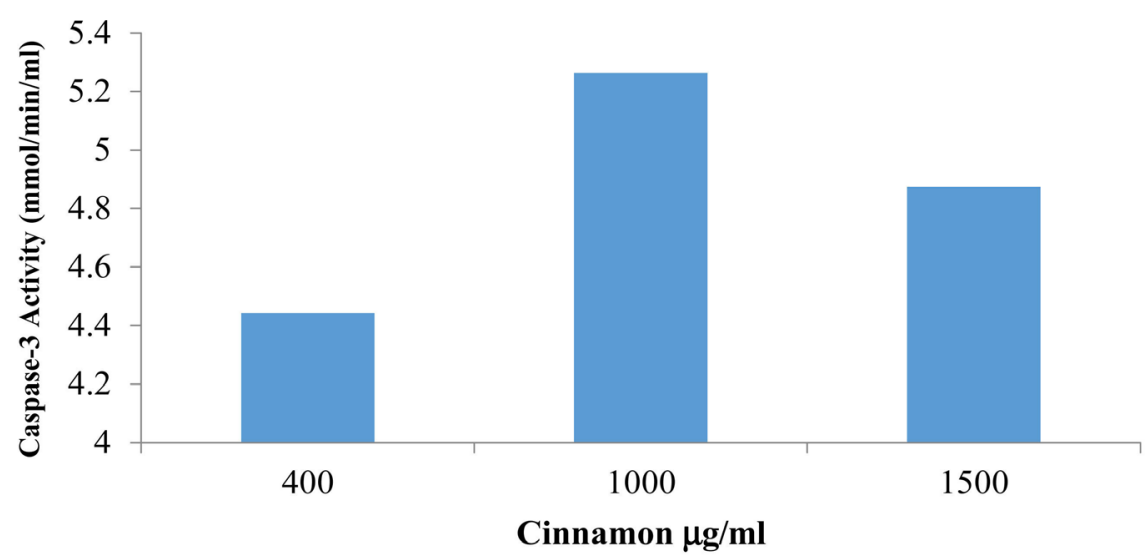

Figure 8. Caspase-3 activity in Caco-2 cells treated (24 hours) with cinnamon extract.

$1500 \mu \mathrm{g} / \mathrm{ml}$ ) in percent cytotoxicity where an increased concentration resulted in a decreased LDH release. This suggests that cinnamon at 1000 and $1500 \mu \mathrm{g} / \mathrm{ml}$, not only injured, but also resulted in the death of Caco- 2 cells ultimately leading to the decrease in caspase- 3 activity.

\section{3. $\mathrm{COX}-2$}

Inflammation plays a critical role in the process of carcinogenesis as chronic inflammation can lead to cell initiation, enhance tumor formation and induce angiogenesis [29]. Cyclooxygenases are enzymes that play a role in the regulation of bodily functions. The 2 isoenzymes of cyclooxygenase include COX-1 and COX-2, where COX-1 is constitutively present in the body and COX-2 is induced, leading to inflammatory responses [40]. Cox-2 percent inhibition was measured to determine anti-inflammatory properties of the herbal teas and cinnamon.

Figures 9-12 show COX percent inhibition of Caco-2 cells treated with herbal teas and cinnamon with respect to the control. Raspberry leaf, strawberry leaf, hibiscus and cinnamon extracts inhibited COX-2 activity, suggesting the anti-inflammatory potential of herbal teas and spice. A dose response in regards to COX-2 inhibition was observed in hibiscus and cinnamon extracts, where enzyme inhibition ranged from $0.70 \%-2.28 \%$ in hibiscus extract and $1.85 \%-$ $5.03 \%$ in cinnamon extracts. COX-2 inhibition in Caco-2 cells treated with raspberry leaf extracts ranged from $0.59 \%-1.69 \%$; strawberry leaf extract $(0.8$ $\mathrm{mg} / \mathrm{ml}$ ) exhibited the highest anti-inflammatory potential by inhibiting COX-2 activity by $8.13 \%$.

\subsection{Cell Morphology and DNA Fragmentation}

The effects of herbal teas and spices on cell morphology are shown in Figure 13. The membrane of cells not treated with tea or spice extracts (Control) (Figure 13(a)) was intact. On the other hand, apoptotic blebbing of cells treated with raspberry leaf (Figure 13(b)), strawberry leaf (Figure 13(c)), hibiscus (Figure 13(d)) and cinnamon (Figure 13(e)) was observed. 


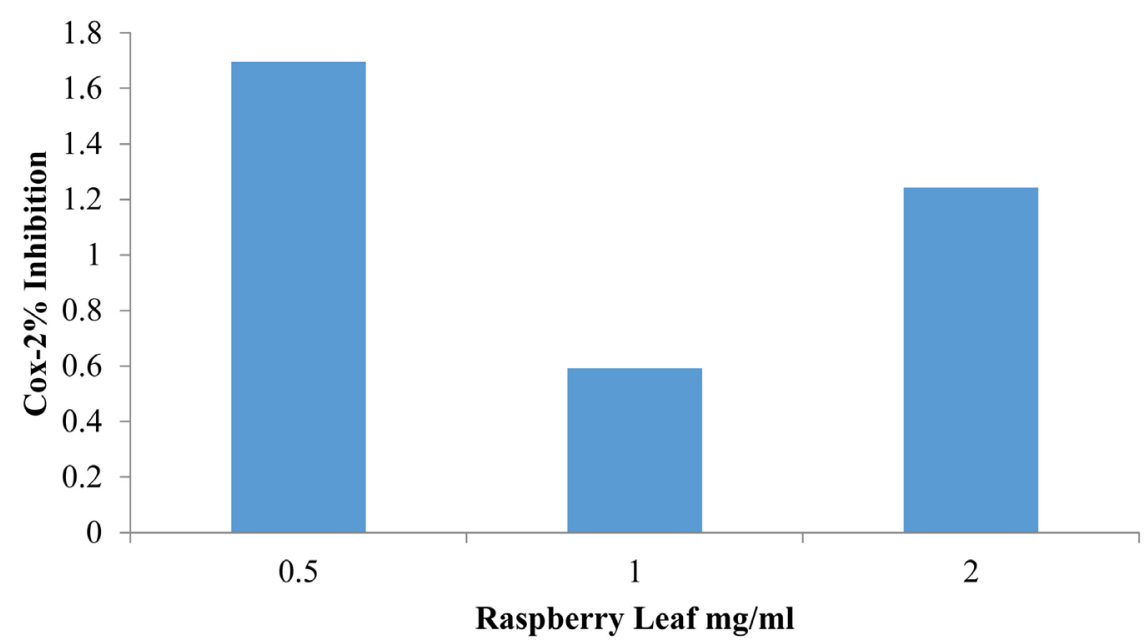

Figure 9. COX-2 percent inhibition in Caco-2 cells treated (24 hours) with raspberry leaf extract.

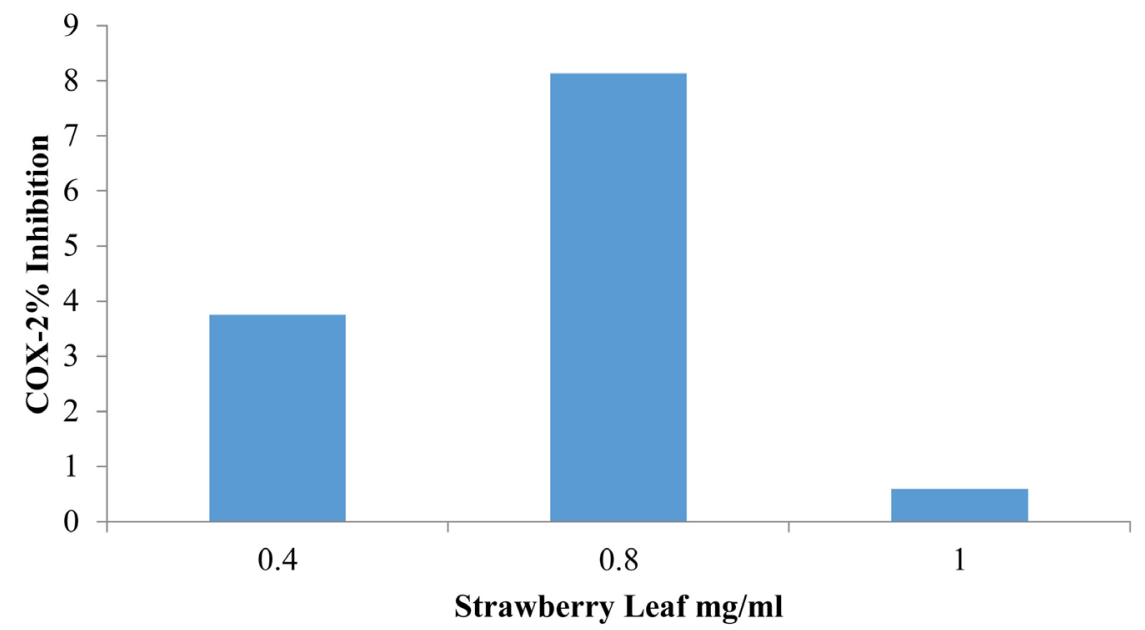

Figure 10. COX-2 percent inhibition in Caco-2 cells treated (24 hours) with strawberry leaf extract.

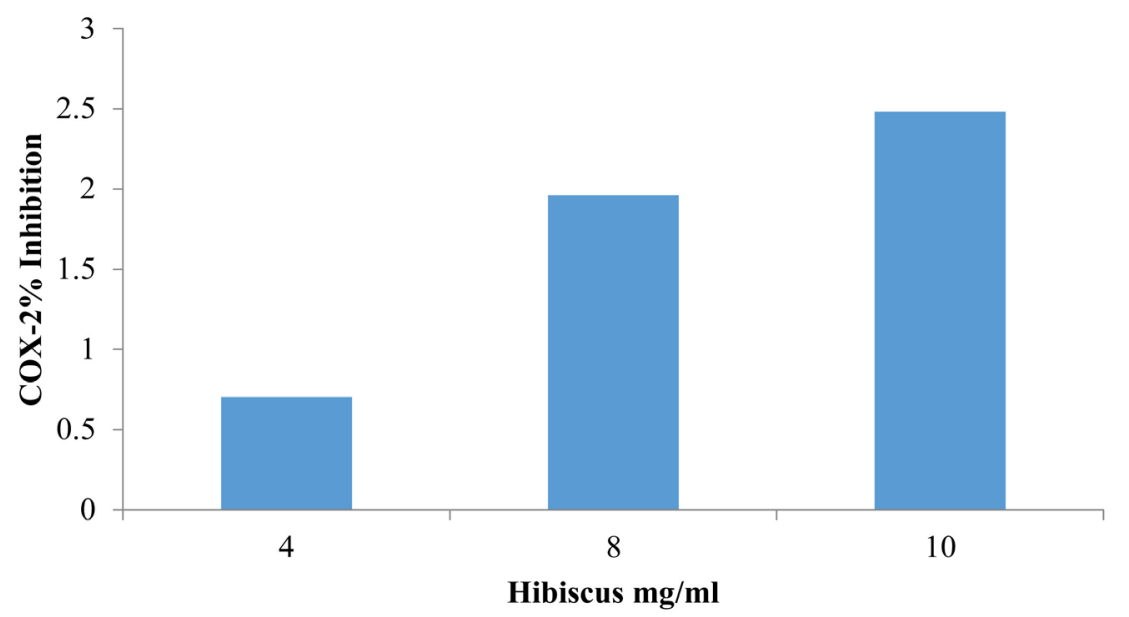

Figure 11. COX-2 percent inhibition in Caco-2 cells treated (24 hours) with hibiscus extract. 


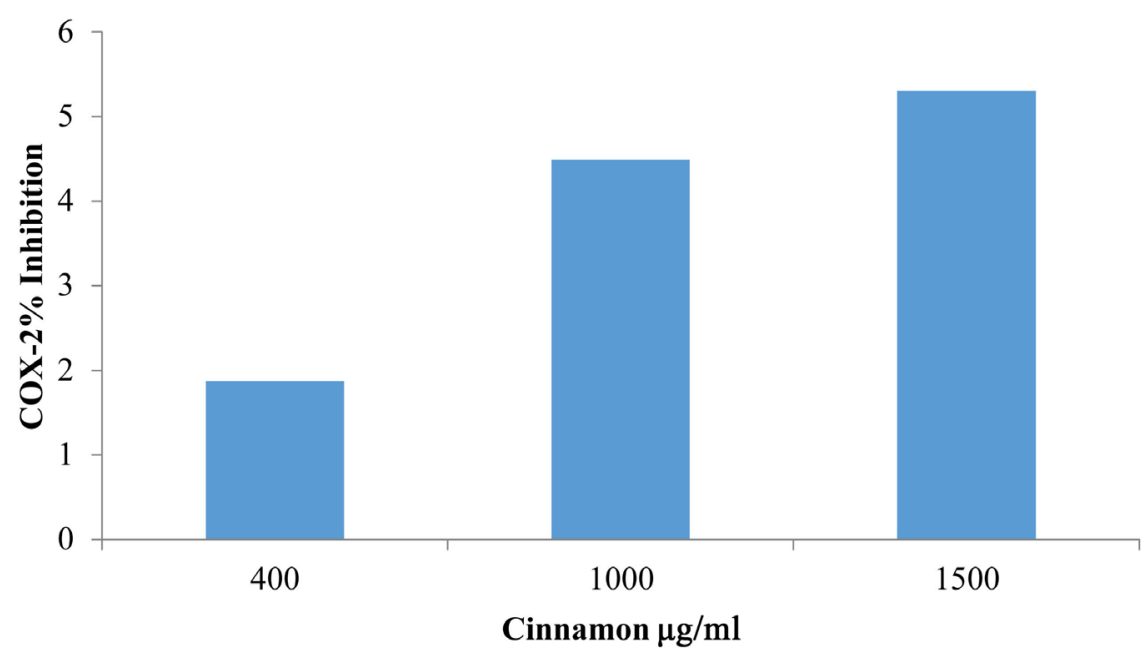

Figure 12. COX-2 Percent Inhibition in Caco-2 cells treated (24 hours) with Cinnamon extract.

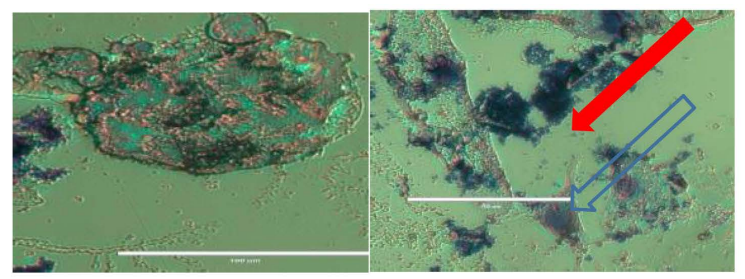

(a)

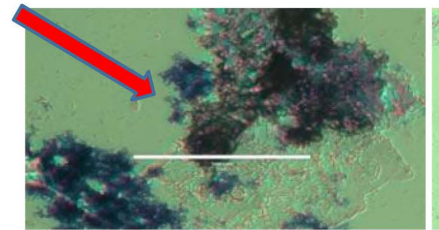

(c)

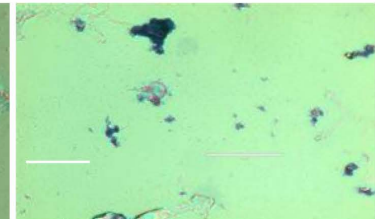

(d) (b)

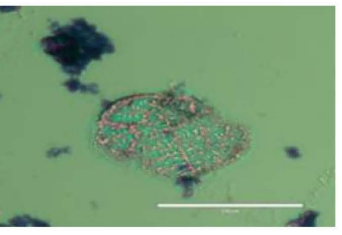

(e)

Figure 13. Wright-Giemsa staining of Caco-2 cells treated with (a) Control; (b) Raspberry Leaf $0.5 \mathrm{mg} / \mathrm{ml}$; (c) Strawberry Leaf $0.8 \mathrm{mg} / \mathrm{ml}$; (d) Hibiscus $10 \mathrm{mg} / \mathrm{ml}$; (e) Cinnamon $1500 \mu \mathrm{g} / \mathrm{ml}$.

Figure 14 shows cellular DNA fragmentation in Caco-2 cells treated with herbal teas and spices, expressed as enrichment factor (EF). For all extracts EF increased with increasing concentration, with the exception of Caco-2 cells treated with raspberry leaf extract, where there was no change observed. DNA fragmentation is a direct reflection of the apoptosis-inducing effects of herbal teas and spices.

The anti-carcinogenic properties of raspberry leaf, strawberry leaf, hibiscus and cinnamon were exhibited through various experiments conducted in vitro. Inflammation is implicated in the initiation and promotion of cancer, and it has been suggested that herbal teas have anti-inflammatory properties. In a study conducted by Trouillas et al., 16 plants that are commonly consumed in the form of tea were found to have anti-inflammatory as well as anti-proliferative effects [41]. The anti-inflammatory property of herbal teas and spices in the 


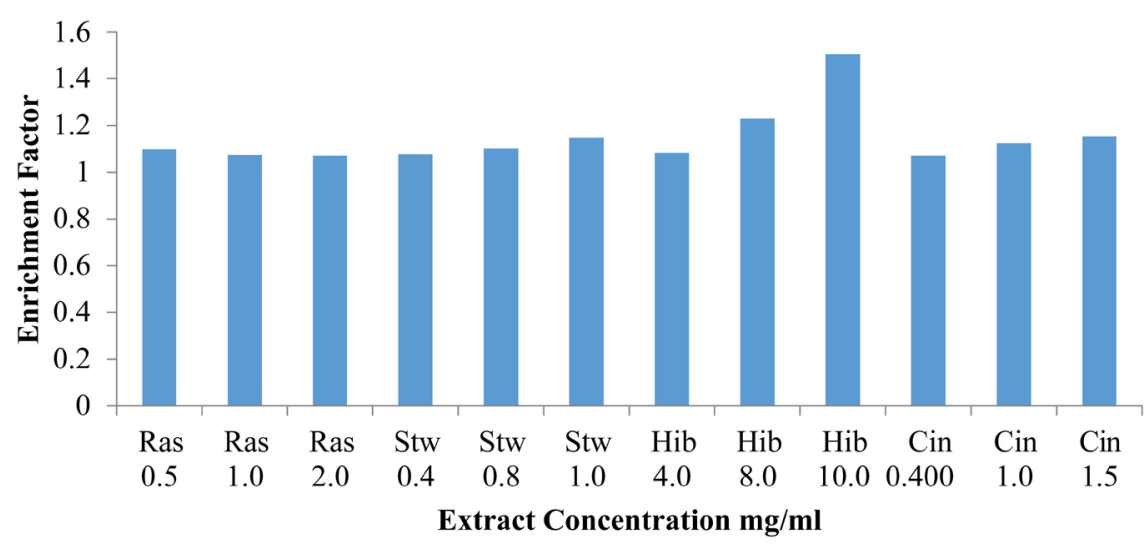

Figure 14. Cellular DNA Fragmentation in Caco-2 cells treated with Raspberry Leaf, Strawberry Leaf, Hibiscus, and Cinnamon. Abbreviations: Ras-raspberry leaf, Stwstrawberry leaf, Hib-hibiscus flower, Cin—cinnamon.

present study was evaluated via the inhibition of COX-2.

The present results align with findings from Sadava et al., where epigallocatechin from green tea was seen to induce apoptosis in cancer cells [42]. Extracts in the present study were seen to induce apoptosis by increasing caspase- 3 activity.

The induction of apoptosis was confirmed by evaluating DNA fragmentation. The EF shows the ratio of DNA fragments released from the control and samples. The increased EF signifies that apoptosis was induced by the herbal tea and spice extracts. The results of this study suggest that the herbal teas and cinnamon studied have chemopreventive properties and maybe beneficial in the prevention of cancer.

The present study addressed methanolic extracts of herbal tea and cinnamon; further research is needed to determine the effects of ethanolic and aqueous extracts on cells. The present study also focused on hibiscus flower; common by-products of hibiscus tea include hibiscus foliage. Continued research should determine effects of foliage on cells as well.

\section{Conclusion}

Traditional and herbal teas have been used for centuries to treat a wide range of ailments. Traditional teas are derived from the tea plant, while herbal teas are derived from other plants. Herbal teas and spices have been seen to be abundant sources of phytochemicals, with increasing popularity in the US market. Though there are many reports on the anti-cancer effect of traditional teas, there are few reports on the chemopreventive potential of herbal teas including strawberry leaf, raspberry leaf and hibiscus teas. In the present study, chemopreventive and anti-inflammatory potential (in vitro) of teas and spices was evaluated. Our results indicate that strawberry leaf, raspberry leaf, hibiscus, and cinnamon exhibit chemopreventive and anti-inflammatory potential against colon cancer in a Caco-2 colon cancer cell model. With the rise in the incidence of chronic diseases, the food industry has increased its focus on food products with health benefits. There is a definite need for more research in the area of underutilized plant teas 
in regards to the prevention of other chronic diseases. Human clinical trials will be needed to determine this and provide public health recommendations.

\section{Conflicts of Interest}

The authors declare no conflicts of interest regarding the publication of this paper.

\section{References}

[1] ACS (2017) Colorectal Cancer Facts and Figures. American Cancer Society. https://www.cancer.org/content/dam/cancer-org/research/cancer-facts-and-statistic $\underline{\text { s/colorectal-cancer-facts-and-figures/colorectal-cancer-facts-and-figures-2017-2019 }}$ pdf

[2] Willett, W.C. (2000) Diet and Cancer. The Oncologist, 5, 393-404. https://doi.org/10.1634/theoncologist.5-5-393

[3] Williams, D., Verghese, M., Walker, L.T., Boateng, J., Shackelford, L. and Chawan, C.B. (2007) Flax Seed Oil and Flax Seed Meal Reduce the Formation of Aberrant Crypt Foci (ACF) in Azoxymethane-Induced Colon Cancer in Fisher 344 Male Rats. Food and Chemical Toxicology, 45, 153-159. https://doi.org/10.1016/j.fct.2006.08.014

[4] Verghese, M., Rao, D.R., Chawan, C.B., Williams, L.L. and Shackelford, L. (2002) Dietary Inulin Suppresses Azoxymethane-Induced Aberrant Crypt Foci and Colon Tumors at the Promotion Stage in Young Fisher 344 Rats. The Journal of Nutrition, 132, 2809-2813. https://doi.org/10.1093/jn/132.9.2809

[5] Divisi, D., Di Tommaso, S., Salvemini, S., Garramone, M. and Crisci, R. (2006) Diet and Cancer. Acta Biomedica-Ateneo Parmense, 77, 118.

[6] Doll, R. and Peto, R. (1981) The Causes of Cancer: Quantitative Estimates of Avoidable Risks of Cancer in the United States Today. Journal of the National Cancer Institute, 66, 1192-1308. https://doi.org/10.1093/jnci/66.6.1192

[7] Halliwell, B. (1996) Commentary Oxidative Stress, Nutrition and Health. Experimental Strategies for Optimization of Nutritional Antioxidant Intake in Humans. Free Radical Research, 25, 57-74. https://doi.org/10.3109/10715769609145656

[8] Benzie, I.F. and Wachtel-Galor, S. (2011) Herbal Medicine: Biomolecular and Clinical Aspects. CRC Press, Boca Raton. https://doi.org/10.1201/b10787

[9] Sun, Y., Tang, X.M., Half, E., Kuo, M.T. and Sinicrope, F.A. (2002) Cyclooxygenase-2 Overexpression Reduces Apoptotic Susceptibility by Inhibiting the Cytochrome Cdependent Apoptotic Pathway in Human Colon Cancer Cells. Cancer Research, 62, 6323-6328.

[10] Jaksevicius, A., Carew, M., Mistry, C., Modjtahedi, H. and Opara, E. (2017) Inhibitory Effects of Culinary Herbs and Spices on the Growth of HCA-7 Colorectal Cancer Cells and Their COX-2 Expression. Nutrients, 9, 1051. https://doi.org/10.3390/nu9101051

[11] Surh, Y.J. (2003) Cancer Chemoprevention with Dietary Phytochemicals. Nature Reviews Cancer, 3, 768-780. https://doi.org/10.1038/nrc1189

[12] Wattenberg, L.W. (1985) Chemoprevention of Cancer. Cancer Research, 45, 1-8.

[13] Sun, J., Chu, Y.F., Wu, X. and Liu, R.H. (2002) Antioxidant and Antiproliferative Activities of Common Fruits. Journal of Agricultural and Food Chemistry, 50, 7449-7454. https://doi.org/10.1021/jf0207530 
[14] Liu, R.H. (2004) Potential Synergy of Phytochemicals in Cancer Prevention: Mechanism of Action. The Journal of Nutrition, 134, 3479S-3485S. https://doi.org/10.1093/jn/134.12.3479S

[15] Oh, J., Jo, H., Cho, R., Kim, S. and Han, J. (2013) Antioxidant and Antimicrobial Activities of Various Leafy Herbal Teas. Food Control, 31, 403-409. https://doi.org/10.1016/j.foodcont.2012.10.021

[16] Kratchanova, M., Denev, P., Ciz, M., Lojek, A. and Mihailov, A. (2010) Evaluation of Antioxidant Activity of Medicinal Plants Containing Polyphenol Compounds. Comparison of Two Extraction Systems. Acta Biochimica Polonica, 57, 229-234. https://doi.org/10.18388/abp.2010_2399

[17] Stoner, G.D., Wang, L.S., Seguin, C., Rocha, C., Stoner, K., Chiu, S. and Kinghorn, A.D. (2010) Multiple Berry Types Prevent N-Nitrosomethylbenzylamine-Induced Esophageal Cancer in Rats. Pharmaceutical Research, 27, 1138-1145. https://doi.org/10.1007/s11095-010-0102-1

[18] Naemura, A., Mitani, T., Ijiri, Y., Tamura, Y., Yamashita, T., Okimura, M. and Yamamoto, J. (2005) Anti-Thrombotic Effect of Strawberries. Blood Coagulation \& Fibrinolysis, 16, 501-509. https://doi.org/10.1097/01.mbc.0000184737.50594.a8

[19] McKay, D.L., Chen, C.O., Saltzman, E. and Blumberg, J.B. (2010) Hibiscus sabdariffa L. Tea (Tisane) Lowers Blood Pressure in Prehypertensive and Mildly Hypertensive Adults. The Journal of Nutrition, 140, 298-303. https://doi.org/10.3945/jn.109.115097

[20] Hirunpanich, V., Utaipat, A., Morales, N.P., Bunyapraphatsara, N., Sato, H., Herunsale, A. and Suthisisang, C. (2006) Hypocholesterolemic and Antioxidant Effects of Aqueous Extracts from the Dried Calyx of Hibiscus sabdariffa L. in Hypercholesterolemic Rats. Journal of Ethnopharmacology, 103, 252-260. https://doi.org/10.1016/j.jep.2005.08.033

[21] Olaleye, M.T. (2007) Cytotoxicity and Antibacterial Activity of Methanolic Extract of Hibiscus sabdariffa. Journal of Medicinal Plants Research, 1, 9-13.

[22] Prasad, K.N., Yang, B., Dong, X., Jiang, G., Zhang, H., Xie, H. and Jiang, Y. (2009) Flavonoid Contents and Antioxidant Activities from Cinnamomum Species. Innovative Food Science \& Emerging Technologies, 10, 627-632.

https://doi.org/10.1016/j.ifset.2009.05.009

[23] Singh, G., Maurya, S. and Catalan, C.A. (2007) A Comparison of Chemical, Antioxidant and Antimicrobial Studies of Cinnamon Leaf and Bark Volatile Oils, Oleoresins and Their Constituents. Food and Chemical Toxicology, 45, 1650-1661. https://doi.org/10.1016/j.fct.2007.02.031

[24] Rao, Y.K., Fang, S.H. and Tzeng, Y.M. (2007) Evaluation of the Anti-Inflammatory and Anti-Proliferation Tumoral Cells Activities of Antrodia camphorata, Cordyceps sinensis, and Cinnamomum osmophloeum Bark Extracts. Journal of Ethnopharmacology, 114, 78-85. https://doi.org/10.1016/j.jep.2007.07.028

[25] Biganzoli, E., Cavenaghi, L.A., Rossi, R., Brunati, M.C. and Nolli, M.L. (1999) Use of a Caco-2 Cell Culture Model for the Characterization of Intestinal Absorption of Antibiotics. IL Farmaco, 54, 594-599. https://doi.org/10.1016/S0014-827X(99)00069-5

[26] Ranaldi, G., Islam, K. and Sambuy, Y. (1992) Epithelial Cells in Culture as a Model for the Intestinal Transport of Antimicrobial Agents. Antimicrobial Agents and Chemotherapy, 36, 1374-1381. https://doi.org/10.1128/AAC.36.7.1374

[27] Alberts, B., Johnson, A., Lewis, J., Raff, M., Roberts, K. and Walter, P. (2002) The Cell Cycle and Programmed Cell Death. 
[28] Ferrero-Miliani, L., Nielsen, O.H., Andersen, P.S. and Girardin, S.E. (2007) Chronic Inflammation: Importance of NOD2 and NALP3 in Interleukin-1 $\beta$ Generation. Clinical \& Experimental Immunology, 147, 227-235. https://doi.org/10.1111/j.1365-2249.2006.03261.x

[29] Coussens, L.M. and Werb, Z. (2002) Inflammation and Cancer. Nature, 420, 860867. https://doi.org/10.1038/nature01322

[30] Monteiro, R. and Azevedo, I. (2010) Chronic Inflammation in Obesity and the Metabolic Syndrome. Mediators of Inflammation.

[31] Shacter, E. and Weitzman, S.A. (2002) Chronic Inflammation and Cancer. Oncology (Williston Park, NY), 16, 217-226.

[32] Dubois, R.N., Abramson, S.B., Crofford, L., Gupta, R.A., Simon, L.S., Van De Putte, L.B. and Lipsky, P.E. (1998) Cyclooxygenase in Biology and Disease. The FASEB Journal, 12, 1063-1073. https://doi.org/10.1096/fasebj.12.12.1063

[33] Mazhar, D., Gillmore, R. and Waxman, J. (2005) COX and Cancer. QJM, 98, 711-718. https://doi.org/10.1093/qjmed/hci119

[34] Nam, S.H., Choi, S.P., Kang, M.Y., Kozukue, N. and Friedman, M. (2005) Antioxidative, Antimutagenic, and Anticarcinogenic Activities of Rice Bran Extracts in Chemical and Cell Assays. Journal of Agricultural and Food Chemistry, 53, 816-822. https://doi.org/10.1021/jf0490293

[35] Sutherland, J.E. and Costa, M.A.X. (2003) Epigenetics and the Environment. Annals of the New York Academy of Sciences, 983, 151-160. https://doi.org/10.1111/j.1749-6632.2003.tb05970.x

[36] Yuan, J., Angelucci, E., Lucarelli, G., Aljurf, M., Snyder, L.M., Kiefer, C.R., Schrier, S.L., et al. (1993) Accelerated Programmed Cell Death (Apoptosis) in Erythroid Precursors of Patients with Severe Beta-Thalassemia (Cooley's Anemia) [See Comments]. Blood, 82, 374-377.

[37] Alnemri, E.S., Livingston, D.J., Nicholson, D.W., Salvesen, G., Thornberry, N.A., Wong, W.W. and Yuan, J. (1996) Human ICE/CED-3 Protease Nomenclature. Cell, 87, 171. https://doi.org/10.1016/S0092-8674(00)81334-3

[38] Shi, Y. (2002) Mechanisms of Caspase Activation and Inhibition during Apoptosis. Molecular Cell, 9, 459-470. https://doi.org/10.1016/S1097-2765(02)00482-3

[39] Jonges, L.E., Nagelkerke, J.F., Ensink, N.G., van der Velde, E.A., Tollenaar, R.A., Fleuren, G.J., Kuppen, P.J., et al. (2001) Caspase-3 Activity as a Prognostic Factor in Colorectal Carcinoma. Laboratory Investigation, 81, 681. https://doi.org/10.1038/labinvest.3780277

[40] Fitzpatrick, F.A. (2004) Cyclooxygenase Enzymes: Regulation and Function. Current Pharmaceutical Design, 10, 577-588. https://doi.org/10.2174/1381612043453144

[41] Trouillas, P., Calliste, C.A., Allais, D.P., Simon, A., Marfak, A., Delage, C. and Duroux, J.L. (2003) Antioxidant, Anti-Inflammatory and Antiproliferative Properties of Sixteen Water Plant Extracts Used in the Limousin Countryside as Herbal Teas. Food Chemistry, 80, 399-407. https://doi.org/10.1016/S0308-8146(02)00282-0

[42] Sadava, D., Whitlock, E. and Kane, S.E. (2007) The Green Tea Polyphenol, Epigallocatechin-3-Gallate Inhibits Telomerase and Induces Apoptosis in Drug-Resistant Lung Cancer Cells. Biochemical and Biophysical Research Communications, 360, 233-237. https://doi.org/10.1016/j.bbrc.2007.06.030 